\title{
A Dêixis como um "Complicador/facilitador" no contexto COGNITIVO E LINGÜÍSTICO EM AMBIENTE EDUCACIONAL FACE AOS ALUNOS COM DEFICIÊNCIA VISUAL

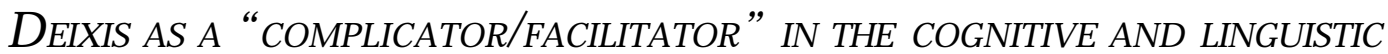 \\ CONTEXT IN EDUCATIONAL ENVIRONMENT CONCERNING STUDENTS WITH VISUAL \\ DISABILITY
}

\author{
SantaTerezinhaFal cadeLAVARDA ${ }^{1}$ \\ JorgeBIDARRA 2
}

\begin{abstract}
RESU M O : chama-se dêixis a expressão de referenciação lingüística que tem por função relacionar, no ato de enunciação, certas unidades gramaticais às coordenadas espaço-temporais. O uso de dêiticos ao longo deuma exposição oral éum recurso bastantefreqüentee, na maioria das vezes, indispensável. Nesse artigo, tomamos como ponto deobservação, fal as de professores em sal a deaula, de uma forma genérica. N elas temos verificado que o uso do dêitico, principalmente o espacial que necessita da articulação visual/ auditiva, quando não trabal hado com cuidado eatenção pel o professor, constitui um problema sério. Desenvolvemos, a partir daí, uma discussão teórica, preliminar, a respeito da dêixis, bem como o impacto que a dêixis surte sobre um público muito particular de estudantes com deficiência visual (DVs). Um resgate teórico sobreas categoriase os objetos de discurso pel os quais os sujeitos compreendem o mundo éfeito aqui.
\end{abstract}

PA LAV RA S-CH AV E: al unos com deficiência visual; dêixis; linguagem e cognição; educação especial.

A BST RACT: Deixis means the linguistic referencing expression the function of which is to relate, during the act of enunciation, certain grammatical units to space-time coordinates. The use of deictics throughout oral exposition is a very frequent and usual ly essential device. In this article, thestarting point for the observation are teachers' enunciations in the classroom, considered generically. In these speeches, we have identified that the use of deictics, especially spatial ones, constitutes a serious problem when not carefully and attentively dealt with by the teacher. Based on this phenomenon, we have carried out a theoretical discussion, still in preliminary stages, on deixis and on its impact on a very particular audience, madeup of students with visual disability. This paper presents a theoretical review of the categories and objects of discourse by means of which the subjects understand the world.

KEYWORD S: learners with visual disability; deixis; language and cognition; special education.

\footnotetext{
${ }^{1}$ Mestranda de Letras pelaUN IOESTE; Coordenadora eProfessora do N úd eo de A poio Pedagógico do CA P Centro deA poio Pedagógico para A tendimento às Pessoas com Deficiência Visual - santatel @hotmail.com.

${ }^{2}$ Lingüista Computacional, Professor Adjunto do Centro de Ciências Exatas eTecnológicas da Universidade Estadual do Oeste do Paraná - UN IOESTE, Curso de Graduação de Informática nas áreas de Inteligência Artificial eTecnologias Assistivas. Professor de Mestrado de Letras na Á rea de Processamento de Linguagem Natural eLingüística Computacional - jbidarra@unioeste.br.
} 


\section{INTRODUÇÃO}

A língua ea comunicação estabelecem entresi uma relação intrínseca indispensável (PERROT, 1970). Existem vários tipos de comunicação usados para externar pensamentos. Os modos mais frequentemente usados, no entanto, são os orais, auditivos e visuais. As possibilidades de comunicação remanescentes, tais como as táteis, as gustativas e as olfativas, na maioria das vezes, apenas desempenham um papel secundário esubordinado aos anteriores, especial mente quando se trata de processos de comunicação deuso delinguagem padrão.

Essa situação, todavia, se modifica, desdequeas pessoas nem sempre seenquadram nesse dito padrão, o qual pressupõequetodos usufruem das mesmas condições, sejam elas denatureza física ou cognitiva.

A despeito dos muitos avanços realizados no campo da compreensão das línguas, o fato équeos modos decomunicação visual edaqueles que antes nos referimos como secundários passam a assumir uma posição de destaque quando o queestáem jogo são os indivíduos queapresentam al gumalimitação sensório-motora. Assim éo caso das pessoas com deficiência visual (cegos ou com baixa visão).

A questão de comunicação que aqui será discutida leva em conta justamente essa situação e o faremos à luz de um problema que, se antes ficava à margem dos debates científicos, hoje é pal co de discussões acaloradas, em busca desoluções que possam garantir a esses indivíduos melhor condição de acesso ao conhecimento.

A linguagem depende de um amplo conjunto de elementos quefalante eouvinte precisam dominar para garantir a comunicação. N as relações sociais entre ambos, além dos limites do dizer edo calar, faz-senecessário o uso de um conteúdo adequado, sujeito a regras que governam a produção apropriada dos atos de fala. Num contexto dialógico, por exemplo, todo falante, mesmo quenão tenha consciência disso, usa a linguagem como um sistema de sinais organizados. Para Perrot, as manifestações da linguagem representam uma função humana baseada na associação dos conteúdos do pensamento com os sons produzidos pela fala. Embora essesistema seja constituído, na base, por palavras, em quea grandemaioria delas possui forte teor semântico, o fato é que em circunstâncias diversas fazer uso de elementos referenciais para ajudar tanto o emissor na exposição desuasidéias quanto o ouvinte na compreensão do quelheé dito, torna-seum recurso indispensável.

N uma conversação aberta, por exemplo, émuito comum o uso da dêixis. Ao lançar mão desse expediente, o falante examina o manejo da continuidade referencial, verifica a incidência de construção de frases coesivas e coer en tes ${ }^{3}$, tudo

\footnotetext{
${ }^{3}$ Segundo Koch (1993), a coerência se estabel ece pel o princípio da cooperação, na interação e na interlocução entre dois usuários. Ela faz com que o texto faça sentido para estes; é semântica e pragmática, é profunda e não-linear. A coesão, por sua vez, éexplicitamenterevelada através demarcas lingüísticas, índices formais na estrutura da seqüência lingüística e superficial do texto. É linear, sintática e gramatical, porém, forma uma espécie de par opositivo/ distintivo com a coerência. É semântica quando se trata da relação de, entre um e outro elemento, crucial para a sua interpretação.
} 
isso com o objetivo degarantir o efeito desejado sobre o ouvinte daquilo queele, o emissor, está tentando transmitir. A presença do dêitico, por suas características, acompanhado por elementos de indicação, atitudes, gestos, expressões faciais ou ol hares, na grande maioria das vezes, exige compreensão a partir da intrínseca articulação entre, pelo menos dois órgãos dos sentidos humanos, audição evisão.

Num contexto em que vários elementos lingüísticos e extralingüísticos estão em constante negociação em tal estado de coisas, não há como deixar de considerar as diversas situações que dão às línguas um caráter ao mesmo tempo complexo, dinâmico e deinteresse particular.

Embora válido e, em via de regra, plenamente aceito pelos fal antes, o propósito aqui é colocar em evidência o impacto negativo causado pelos dêiticos espaciais, quando o seu uso não écercado de cuidados necessários para a efetivação do enunciado. O foco da discussão são os al unos com deficiência visual, daqui por diante, apenas referidos por DVs, tomando como ponto de partida as condições de acesso ao conhecimento que as escolas Ihes estão ofertando.

A metodologia adotada para essa discussão se baseia em observações feitas no entorno das relações estabelecidas entre professores e alunos DVs em situação de sala de aula, notadamente na transmissão do conhecimento via exposições orais didáticas. Para tanto, abordaremos a dêixis sob dois enfoques, um estrutural e outro funcional. N essa apresentação, serão considerados também alguns aspectos teóricos importantes e que têm servido de base para a sustentação do trabal ho em curso. Começamos o debate pelo estabelecimento do quevem a ser o sentido dado ao termo DV, para os objetivos aqui propostos.

\section{Avaliação funcional da VISÃo}

Nesse trabalho, são considerados DVs todas as pessoas que não enxergam ou quetenham problemas visuais graves, sem quenecessariamentesejam cegas. No âmbito educacional, o conceito de DV tem partido de uma avaliação funcional da visão. Segundo Cartilha apresentada pelo Ministério da Educação (BRA SI L, 2001), cegas seriam as pessoas que apresentam desde ausência total de visão até a perda da projeção deluz, para os quais o contato com o mundo se fará através dos sentidos remanescentes (tato, audição, olfato, paladar). Baixa visão, nessa assunção, seria a alteração da capacidade funcional da visão, decorrentede inúmeros fatores isolados ou associados, tais como: baixa acuidade visual significativa, redução importante do campo visual, alterações corticais e/ ou de sensibilidade aos contrastes que interferem ou limitam o desempenho visual do indivíduo. Para fins legais eadministrativos, a Oftal mologia classifica uma pessoa 
como cega sea sua acuidade visual for da ordem de20/200 na escala optométrica decimal - tabela deSnellen ${ }^{4}$, no mel hor olho, com correção adequada.

Em maior ou menor escala, qualquer pessoa com a sua capacidade visual prejudicada precisa utilizar os demais sistemas sensoriais para reconhecimento do mundo quea cerca. Para pessoasDVs, o tato ativo, por exemplo, desempenha uma função primordial enecessária para a coleta de informações; a audição, por outro lado, éusada para a comunicação verbal ecomo tele-receptora para localizar eidentificar pessoas eobjetos no espaço; o olfato, para reconhecimento de ambientes e pessoas. Esses sentidos, como um todo, ficam mais acentuados no DV, desde que deles dependa para melhor orientação e mobilidade, assumindo uma via al ternativa distinta ${ }^{5}$.

As inúmeras causas que provocam a redução da acuidade visual também levama diferentes situações deordem funcional do sentido da visão. Tentar compreender como cada aluno DV se organiza esaber o que el e real mente consegue fazer nessas condições é de extrema importância para o bom andamento escolar.

\section{A deficiênCia Visual e a APRendizagem}

Deuma maneira geral, para a transmissão de um conhecimento, todos nós, de uma forma ou outra, necessitamos lançar mão de recursos lingüísticos. Durantea comunicação oral, a linguagem seapresenta como um complexo processo denegociação entre, pelo menos, duas pessoas, o falanteeo ouvinte. Quando ambos se encontram nas mesmas condições de enunciação e recepção, a comunicação tende a acontecer. Todavia, quando ocorre num ambiente fora de sintonia, a comunicação se frustra.

Desfazendo um mito quehá muito prevalecenos meios educacionais, a maior parte das pesquisas recentemente realizadas dá mostras de que o aproveitamento dosalunos DVs, diferentementedo queseacreditava atébem pouco tempo, é equivalente ao dos alunos videntes. Como qualquer estudante, os DVs podem apresentar dificuldades no desenvolvimento educacional, mas que nada teria a ver, em princípio, com problemas de natureza cognitiva. Se assim é, esse

\footnotetext{
${ }^{4} \mathrm{~A}$ tabela de Snellen é composta de letras al eatórias, dispostas em filei ras, em tamanhos diferenciados, destinadas a medir a acuidade visual para longe. Cada fileira édesignada por um número queo ol ho seria capaz de ler à distância medida em pés. A ssim, a visão normal, capaz de ler a menor fileira da tabela érepresentada pela fração 20/ 20, ou seja, o numerador da fração indica que, numa distância de 20 pés ( 6 metros) entrea pessoa e a tabela, a mesma pode ler o tamanho 20 (denominador da fração). Essa escala vai modificando o val or do denominador à medida que reduz a acuidade visual do indivíduo. A ssim, numa razão 20/60, indicação éde que a capacidade visual da pessoa permite-lheler atéa linha 60 numa distância de 20 pés.
}

${ }^{5}$ Segundo Vygotsky (1997), os DVs não desenvolvem os órgãos dos sentidos, esim abrangem inteiramentea personali dadeem seu conjunto, começando por seu núcleo interno; não tendem a substituir visão, mas, vencer esupercompensar o conflito social ea instabilidade psicológica como resultado do defeito físico. 
debate precisa ser reenfocado: o trabalho das escolas e dos professores não deve ficar tão centrado nesse ponto. Antes, mais produtivo, é tentar descobrir meios eficazes de levar aos alunos com deficiência, deuma maneira geral, e, em particular, aos DVs, o conhecimento.

Conforme Coll (2004, p.153), quando, nos diferentes contextos educativos em que crescem as crianças cegas, a intenção é satisfazer suas necessidades especiais, épreciso 'analisar cuidadosamenteas vias al ternativas de quetais crianças dispõem para construir seu desenvolvimento'. A pesar deo autor ter se referido especificamente aos cegos, é fato que os cuidados devem ser estendidos também aos alunos de baixa visão. Estes, na maioria das vezes, passam despercebidos em sala, seja porque el es próprios tentem esconder a sua condição ou porque, pelo fato de não serem cegos, os professores tentam tratá-los como alunos videntes. Não obstante, tais alunos, assim como os cegos, também necessitam deatenção especial. E justamente por isso, colocamos o nosso foco nos problemas vivenciados por esses alunos em sal a de aula.

\section{As "armadilhas" presentes nas comunicações orais}

Na composição de um texto ou mesmo deuma simples fala, expressões desvinculadas dos contextos lingüísticos esituacionais, segundo Guimarães (1999, p.12), 'assomam vagas indeterminadas ou ambíguas'. Se para os al unos videntes, o uso de recursos extralingüísticos pelo professor exige já maior atenção, para os al unos DV s essa situação tende a ser mais dramática.

De acordo com Peirce (1995, p.168), 'qualquer comunicação somente se estabelece quando o emissor consegue fazer o seu ouvinte entender o que ele está tentando Ihetransmitir'. Em conversações abertas, émuito comum a ocorrência deelementos não lingüísticos: o hábito deapontar, por exemplo, éum deles. Sendo, pois, um objeto dinâmico, em que pela natureza das coisas, o signo pode apenas indicar, deixando então ao intérprete a tarefa de descobri-lo, a dêixis se torna um caso de uso impróprio para os DVs, na medida em queapela para recursos visuais que, muitas vezes, não podem ser percebidos por esses indivíduos. Por exemplo, quando um professor escreve no quadro a palavra cantar e apontando para ela, diz - este éum verbo de primei ra conjugação, sem produzir oralmente a pal avra que apontou, para os alunos que não vêem ou que têm dificuldade de ver o el emento apontado, a explicação do professor fica indefinida. A o fazer isso, ainda que muitas vezes não perceba, o professor cria uma dificuldade de compreensão que precisa ser levada em consideração.

\section{A Dêixis no contexto lingüístico}

Para A rnauld (1992, p.2), 'falar éexplicar os pensamentos por meio de signos inventados pelos homens'. Para isso são utilizados formas esons, acrescidos de outros elementos complementares. Os signos podem estabelecer, segundo o 
autor, a maneira e também o objeto que servem para exteriorizar tudo o que se passa na mente do enunciador. N uma classi ficação mais geral, enquanto os signos categorizados como artigos, nomes, pronomes, particípios, preposições eadvérbios vão dar significado aos objetos do pensamento; os verbos, as conjunções e as interjeições vão se ocupar da forma edo modo como seestrutura esse pensamento.

Mônica Rector (1985), referindo-se a W. Wundt (1973), enfatiza que é comum definir a comunicação gestual como uma expressão do pensamento estabel ecida entre a fala e a escrita, feita por meio de movimentos visíveis, mas não audíveis. Para ela,

[...] o comportamento gestual éum produto social ecultural mentediferenciado, tal qual a linguagem articulada. E, embora língua e gesto integrem, em sua mútua rel ação, um sistema total de comunicação, há ainda a considerar o papel desempenhado pelo tato, o olfato e o espaço nesse mesmo sistema. (RECTOR, 1985).

Ao relacionar signos lingüísticos com o contexto, todo falante, independente da sua condição devida ou faixa etária, carrega em sua fala elementos extralingüísticos. Em tais condições, para a complementação do discurso oral, parece não haver situação em que os dêiticos deixem deaparecer. Segundo os estudiosos, éem situações correntes de uso da linguagem humana que a dêixis constrói o elo entre uma expressão lingüística e um elemento da situação de enunciação. A situação é tomada como ponto de partida, num ato particular de produção discursiva, feitos pelo sujeito egocêntricoEu, no momento presente.

Dêixis, palavra importada do grego antigo deíknymi, significa, ação de mostrar. Segundo Lyons (1979), o conceito passou a fazer parteda teoria lingüística, tendo sido introduzida para indicar os traços orientacionais da língua relacionados ao tempo eao lugar do enunciado. É na verdade uma referência exofórica que se estabelece entre uma expressão lingüística eum elemento externo ao enunciado. É uma manifestação típica presente na comunicação aberta, com finalidade de enfatizar os referentes e situá-los no momento da enunciação, num determinado espaço, em relação ao emissor eao receptor durante uma conversação. Para llari e Geraldi (2000, p.66), 'os dêiticos real izam os fenômenos da dêixis (ato demostrar), queéum dostraços quedistinguem alinguagem humana das linguagens artificiais.'

Mais do queum princípio importante para a teoria da comunicação, a dêixis se apresenta atualmente como um estatuto lingüístico, muito embora, até bem pouco atrás, não fosse sequer admitida nos círculos mais importantes de estudos das línguas. Para a lingüística moderna, a dêixis passou a ser vista e estudada a partir de palavras que encerram conteúdos demonstrativos e/ ou de localização. Para Guimarães (1999, p.11), 'os dêiticos se identificam como os elementos lingüísticos que mais claramente mostram a presença do emissor no enunciado', realizada numa situação definida pelas coordenadas espaciais e temporais. Ela enfatiza que, Bühler, em sua 'Teoria da Linguagem', descreve os dêiticos como 'sinais que designam, mostrando e não conceituando'. 
Sob esse novo prisma, a dêxis pode ser considerada como uma unidade imprescindível que seencontra não só na oralidade, mas também na escrita, fazendo parte da linguagem como constitutiva da própria experiência, onde o vivido se apresenta recortado em unidades-signos, que passam necessariamentepor estesfiltros imanentes que são as organizações perceptivas e lingüísticas (LAHUD, 1979). Para podermos compreender mel hor qual o seu papel na oralidadeeem ambientes diversos, um estudo mais aprofundado, que começa pela própria concepção do tempo eespaço sobreos mecanismos a serem usados para preencher as lacunas possivelmentedeixadas por alguma incapacidadedo sujeito ouvinte, precisa ser feito.

Parallari (1997) ellari eGeraldi (2000), apesar deo fenômeno da dêixis dar grande agilidade às línguas naturais, as frases com tais elementos só podem ser interpretadas se conectadas com as devidas situações de fala, podendo as informações variar de acordo com cada uma delas. Por exemplo, eu, tu, aqui eagora, palavras com um forte teor dêitico, variam de acordo com o momento da enunciação, no qual estão em jogo não só o ato da fala, mas também o lugar em que esse se processa.

O ambiente referencial criado pela dêixis, conforme Lyons (1987), permite a localização e a identificação de pessoas, objetos e eventos (processos e atividades de quesefala), atuand o tanto na mente de quem fala quanto na daquele que ouve. Para o autor, nos artifícios que ligam uma expressão com seu contexto espacial, temporal ou pessoal, está sempre presentea dêixis referencial.

Segundo a gramática tradicional, há diferentes tipos de dêixis; dentre os quais citam-se os dêticos pessoais (pronomes pessoais, pronomes possessivos, flexão verbal, vocativos e certas formas de tratamento); os dêiticos espaciais (determinantes, pronomes demonstrativos, advérbios apresentativos e certos verbos demovimento); eos dêiticos temporais (advérbios detempo, desinências espećficas detempos verbais - presente, pretérito efuturo).

Conforme Ilari e Geraldi (2000), os demonstrativos, os pronomes pessoais e os tempos dos verbos são exemplos sempre lembrados de ocorrências dêiticas, mas a dêixis é um fenômeno bem mais comum e amplo do que o uso dessas formas.

Nas línguas, de maneira geral, os pronomes eu etu são os principais paradigmas da dêixis. Mas, junto com eles, encontram-se também os advérbios aqui e agora e outros termos que delimitam a instância espacial e temporal, coextensiva e contemporânea ao eu. Por exemplo, no âmbito espacial, os elementos contextuais seguem na mesma linha objetiva do pronome aqui; os temporais, em agora e os pessoais, em ele. Os termos eu, aqui eagora têm por sentido um roteiro que identifica o falante, o local eo momento da fala, respectivamente. Vários são os autores que assumem essa noção lingüística e pragmática de dêixis: LYONS, 1987; BENVENISTE, 1976, 1992; ILARI; GERALDI, 2000; APOTHÉLOZ, 2003; MAIN GUENEAU, 2001. 
Segundo Benveniste(1976), o demonstrativo, com o seu caráter sempre único e particular, desprovido de referência material, é um caso de conversão da linguagem em discurso, caracterizado por referências internas, na qual o uso do eu se enuncia como locutor, dirigido a um tu que também, como o primeiro, deve estar presente no momento da enunciação.

Ilari, Maingueneau eA pothéloz, em seus estudos, citam uma situação particular deoposição dêtica, identificada por pares tais como ir/ vir, trazer/ levar, ondeo enunciador se coloca no centro da cena, para a qual tudo converge. Numa situação de fala, há uma dêixis de lugar envolvida implicitamente e, que, só se distingue pela local ização do seu locutor. Os usos dos verbos ir el evar por exemplo, constituem descrições de movimento que remetem o ouvinte sempre a um outro local em que não se encontra o locutor; ao contrário do efeito provocado pelos verbos vir etrazer.

A compreensão dos dêticos dependenecessariamentedesua articulação com os não dêiticos (ILA RI; GERA LDI, 2000). Já A pothéloz (2003) observa que, em contexto, o falante tende com freqüência a usar ora o dêtico ora o não-dêitico que, embora conduzam para a interpretação do que é dito a um mesmo ponto, diferem do ponto de vista de seu funcionamento. Alternar dêitico e anáfora, por exemplo, numa mesma situação de fala, émuito comum, especialmente, quando da aquisição de uma segunda língua. O autor, reportando-se a Boch (1983) estabelece uma diferenciação entre anáfora e dêixis, num sentido mais funcional ou pragmático. Para ele, há dêixis quando a expressão tem por objetivo desl ocar o campo deatenção para um referente: o foco não está no significado. É necessário queo meio utilizado para identificar o referente se apóie nos parâmetros de tempo, lugar ou pessoa da situação deenunciação. No caso da anáfora, o movimento éoutro: a expressão coloca o referente como foco da atenção.

A pothéloz identifica três tipos de dêixis: (i) a dêixis situacional ou o lugar, o momento da enunciação em queos demonstrativos podem estar presentes; (ii) a dêixis textual, usada para se referir a segmentos, a lugares ea momentos no próprio texto. Caracteriza-se pelo emprego deexpressões indiciais tais como: mais acima, aqui, no próximo capítulo, etc. , comfunção metatextual ${ }^{6}$; (iii) a dêixis da memória ${ }^{7}$, situação na qual o emprego do demonstrativo revela quea representação discursiva do enunciador e a recepção do destinatário não acontecem no mesmo instante. Nesse caso, o referente é evocado no próprio texto, dando ao destinatário a impressão de ter um acesso imediato ao estado cognitivo da enunciação.

Acrescido a esses, encontram-se ainda, os dêiticos espaciais, uma classificação proposta por diversos autores, aqui destacada, tendo em vista a importância assumida em nosso trabal ho depesquisa. Deacordo com Maingueneau

\footnotetext{
${ }^{6}$ Permite organizar o espaço do texto e facilita a orientação do leitor ou do ouvinte neste espaço, (cf. Conte (1981), como citado em A pothél oz (2003, p. 69)).

${ }^{7}$ Segundo A pothél oz, esta designação se devea Fraser, Joly (1980), ea outros autores como Lyonse Kuno, sob a denomi nação de deixis enfática, R. Lakoff, com dêixis emotiva eKleiber, compensamento indicial.
} 
(2001), trata-se de uma relação situacional em que estão em jogo a posição do corpo do enunciador e os seus gestos. Mas, além dessa forma de local ização, outras modalidades existem. Por exemplo, uma de localização absoluta que se dá pelo uso de termos autodeterminados (ex.: Cascavel, no Paraná); uma outra, de local ização cotextual, que se apóia em um elemento do contexto lingüístico. Segundo o autor, em narrativas clássicas, écomum aparecer uma rede de relações queesclarecem as referências espaciais, sem quehaja necessariamentea intervenção da situação de enunciação, como quando acontecequando seaponta o dedo. N este caso, para o leitor conseguir interpretar as referências locais, necessário sefaz ter acesso, às vezes, até mesmo a uma retomada anafórica. Em textos literários, como nos romances mais recentes, segundo ele, o quesetem podido notar éumaliberdade maior quanto à recuperação do referente dos dêiticos espaciais, podendo ocorrer de maneira menos imediata ou mesmo nunca ocorrer. Numa narrativa montada sobre o monólogo interior, por exemplo, o narrador eo herói tendem a semisturar na consciência de um único sujeito. N esse caso, os dêiticos espaciais precisam ser esclarecidos no texto, muitas vezes obtidos por meio de volteios, a fim deelucidar melhor as referências.

Os dêiticos espaciais, assim como os demais, podem ser estudados sob diferentes enfoques teóricos lingüísticos. No esquema ilustrado a seguir, são tomados para análise edistribuição, por exemplo, apenas os aspectos denatureza morfossintática.

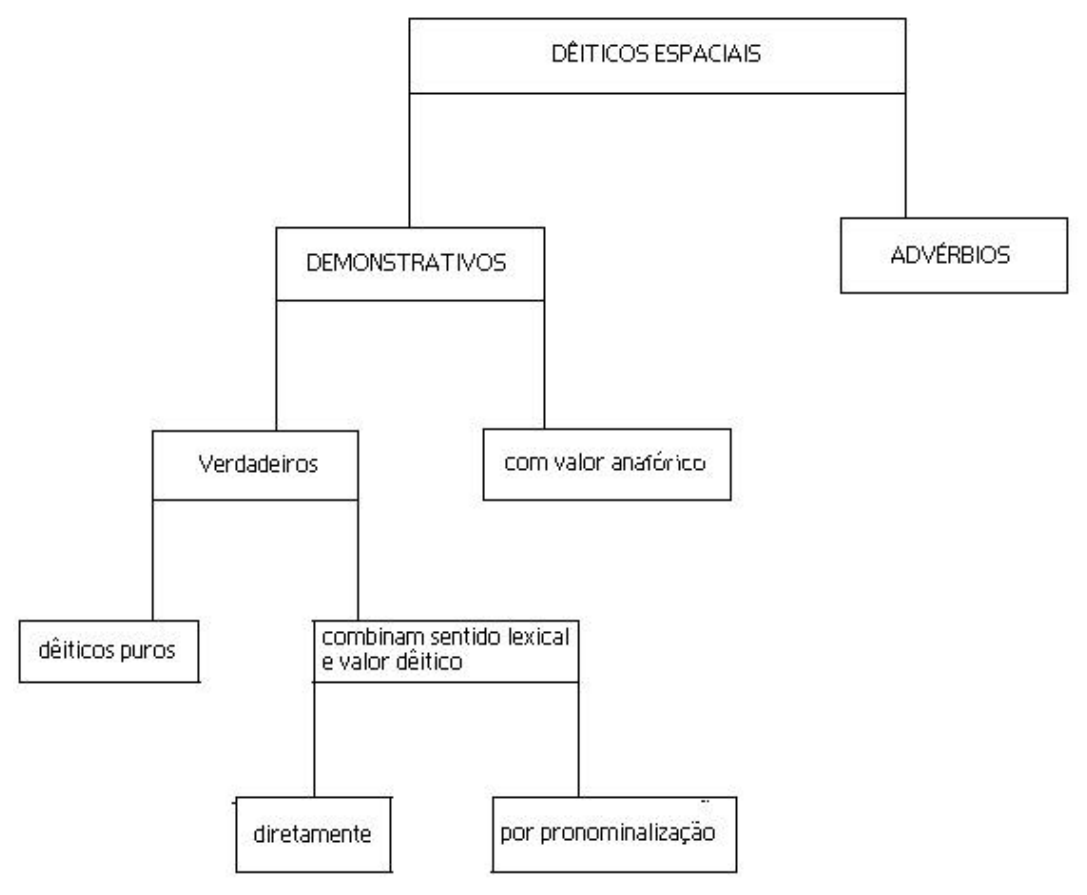


Como mostrado no diagrama, os dêiticos espaciais se distribuem de acordo com a classe gramatical, podendo ser um demonstrativo ou um advérbio. Em se tratando do demonstrativo, conforme a função que desempenha no enunciado, pode assumir um valor ver dadeiro ou anafórico. Os demonstrativos de valor anafórico acontecem quando se dáa retomada de uma unidadejáintroduzida no texto. Os verdadeiros podem se manifestar ou como dêiticos puros, quando acompanhados de um gesto do enunciador (isto, isso, aquilo...) ou como resultado de uma combinação entre o sentido lexical eo valor dêitico. Este último, por sua vez, pode ser realizado de duas formas: diretamente (esta mesa) ou por pronominalização (isto aqui, aquilo lá). Para o autor, os dêiticos adverbiais têm estatuto decomplementos circunstanciais, sempre com valor em função do gesto, da posição ou da orientação do corpo de seu enunciador. Estão distribuídos em diversos micro-sistemas de oposição (perto/longe, na frente/atrás), suscetíveis a mudanças a cada modificação de pelo menos um desses parâmetros.

Segundo Maingueneau (2001), sempre que um indivíduo assume o papel de narrador, fica difícil desconsiderar o uso da localização dêitica. Além do duplo cenário, um em relação à história contada e outro em relação ao narrador, num mesmo momento, existem as localizações, aparentemente mais objetivas e mais independentes do ato da enunciação, quepodem conter em si uma localização do tipo dêtico.

Enquanto, de um lado, os dêiticos espaciais se referem à localização; de outro, os temporais, consideram o momento de fala (também referido como o presente lingüístico). Dentre os dêiticos nessa categoria, estão os de localização absoluta, na qual são trabal hadas expressões precisas, como, por exemplo, datas22 deabril de 1500 eos que se apóiam numa referência no momento da enunciação (hoje, amanhã, há uma semana, daqui a uma semana).

Maingueneau cita ainda uma outra variação para os dêiticos temporais, a que denomina deembreantes temporais. São dêticos com função decomplemento circunstancial, com estatuto deum advérbio ou grupo proposicional, manifestada pela morfologia verbal das marcas do tempo (presente, passado efuturo).

\section{A Dêixis no contexto da sala de aula}

Segundo Benveniste(1976, p.280), 'épela forma verbal queaconteceo ato individual dediscurso'. É neste momento que o locutor torna plenos os signos vazios disponíveis pela linguagem. Por isso, na comunicação intersubjetiva, as formas pronominais remetem a uma enunciação única assumida no discurso.

As falas são impregnadas por expressões dêiticas. Para Lahud (1979), os dêiticos ea linguagem, andando lado a lado, se complementam na intenção de dar significação ao quese diz. A o dizer, por exemplo, dê-meisto, acompanhado de um gesto de designação, o que estaria sendo feito pelo enunciador é um ato completo de referência identificadora, visível aos ol hos das pessoas envolvidas. 
Ao dizer isto, apontando para um objeto, a intenção do falante, não é mais do que apresentar lingüisticamente o objeto a que ele está se referindo mediante um gesto.

Como preconiza Koch (2000), numa comunicação cotidiana, o espaço dêitico éo próprio espaço da atividade defala (situação de interação entreambos). Com presenças marcantes, eminentemente visuais, os dêiticos são usados em comunicações assimétricas, exatamente uma situação em que se encontram, de um lado os professores e de outro, os al unos, nos momentos de aulas expositivas. A pesar de expressões orais e recortes nas falas dos professores, tais como: aqui, lá, isto, veja, todas essas, mostradas no quadro, apresentarem conteúdos semânticos com força representativa, o fato éque por elas mesmas, os verdadeiros significados que trazem ficam, para os DVs, esvaziados.

Não seduvida que os alunos DVs, tal como os videntes, são indivíduos capazes de compreender os sentidos atribuídos a essas palavras/ expressões. Mas, o problema, aqui não se reduz a isso. Para as informações contidas no contexto com dependência de recepção visual, o aluno DV apenas recebe a informação parcialmente, tendo dificuldades de interpretar os locais, à medida que ele, o receptor, desconhece o que foi apontado pelo professor. Cabe aos professores, portanto, construírem uma rede de relações no texto, demaneira queas referências espaciais que el es fizeram se aclarem.

Ao expor para uma turma que uma figura está desenhada no topo do quadro, por exemplo, será necessário da partedos alunos, primeiro, identificarem esselugar. Mesmo que, ainda nesse caso, o aluno DV consiga fazer tal identificação, por exemplo, pelo tato, a mensagem Ihe chegará truncada. Ora, desde que os recursos visuais e auditivos são fundamentais para completar com sucesso a semântica contida na dêixis, para um aluno DV , os recursos usados precisam ser enriquecidos com outros elementos, justamente para suprir a falta ou a dificuldade de visão. Um deles seria, por exemplo, o professor explorar mais os recursos lingüísticose, não sendo possível eliminá-los, usar um pouco menos visual . Alguma coisa do tipo escrevi no quadro a palavra cantar. Pois bem, cantar é um verbo..., com certeza, beneficiaria o al uno DV. Segundo Cazacu (1979), 'A linguagem supõe, na sua forma complexa e normal, uma intenção de comunicar, bem como a possibilidade de real izar esta comunicação a fim de poder efetuar a expressão e sua compreensão'. Em se tratando de um ouvinte DV, cabe ao fal ante fornecer soluções aplicáveis com as devidas adequações que sistematizem a inter-rel ação entre este e o seu ouvinte, de modo a, em conjunto, migrarem os dois para um campo comum de conversação. Sabe-se que o entendimento do ouvinte se dá via sentidos remanescentes. O espaço dêitico é local onde estão presentes, além da fala, os sistemas cognitivos, conjugados pelo conhecimento e pela realidade. A contece quea real idadeaqui referida se dá num contexto em queou a visão está total menteausente ou com limitação de toda ordem graves. 
A aprendizagem significativa é, de todas as maneiras, o conhecimento adquirido a partir da própria experiência do indivíduo. No construtivismo, o aprendiz compreendeo mundo através da própria elaboração quefaz dos fatos. A construção do conhecimento somenteépassível deacontecer na presença do outro. É justamente nesse ambiente, repleto de características diferenciadas, que se encontram os elementos dêiticos ora complicadores ora facilitadores, dependendo do tratamento a eles conferidos. Como bem observa Fragoso (2003),

[...] expressões dêiticas servem de construtores de significado, uma vez que são elas quefornecem as dicas para a significação enquanto o discurso acontece. Fato este que comprova que o significado éal go quese constrói no momento da interação, considerando-se os participantes, o contexto em que estão inseridos, eas conexões feitas por el es a partir da criação dos Espaços Mentais.

Na relação professor/ aluno DV em sala de aula, a língua, como meio de comunicação oral, estará sempre a exigir um trabal ho de refinamento e maior adaptação para os fins a que se propõe. Segundo Geraldi (1996), cruzam-se no presentedo discurso, o passado trazido pela linguagem e a memória de um futuro possível, construído através da linguagem. Para quem utiliza os sentidos remanescentes mais acentuadamente, como éo caso dos DVs, a linguagem é, sem dúvida alguma, uma presença marcante para a compreensão dos assuntos pedagógicos, de modo a trazer de forma oral, sucessões de ações mentais ou materiais aplicadas em tais situações.

Na presença do dêitico espacial, em particular, os alunos DVs ficam expostos à perigosos espaços vazios de fala, incapazes de serem preenchidos justamente pelo fato denão verem. Valendo-se de quadro egiz, o professor precisa reelaborar e reestruturar as suas falas, proporcionando a esses seus al unos uma pontecom o mundo externo, não visível ou de difícil percepção pela visão limitada. Descrever oralmente o significado do dêitico éuma forma de interpretar para esse aluno aquilo que é possível mostrar. Tal comportamento permitirá ao ouvinte construir, em seu mapa mental, o reconhecimento e a compreensão da situação trabalhada em tempo real.

Rector (1985) afirma que, ao se fazer uma investigação do gesto, necessário sefaz ir além da semântica circunscrita ao domínio puramenteverbal. Segundo a autora, é preciso levar em conta a relação do objeto com o referente; considerar o signo em relação ao seu veículo, ao seu usuário e aos seus efeitos, numa segmentação tripartida da semi ótica ou teoria geral dos signos (semiologia da língua, acrescida do gesto não-verbal, numa dimensão pragmática). Porém, diremos nós, também isso por si só seriainsuficiente. Mais apropriado seria, associar dois elementos, o verbal e o gestual. Todavia, se falta capacidade visual para perceber os gestos, não resta ao indivíduo senão preencher as lacunas contidas na exposição oral dêitica com explicações enriqueci das linguisticamente. É com essa hipótese quetrabal hamos. 
Tais indicativos servem para nos mostrar a necessidade de estarmos motivados e integrados com o que seria de papel desempenhado pela dêixis na fala dos indivíduos e, mais especificamente, daqueles que dela dependem para passar algum conhecimento formal e científico. A brir um novo espaço de estudos e aprofundar as discussões em relação a um assunto que, pelo que parece, está apenas começando, é, pois um desafio que todos nós, professores, educadores e alunos precisamos enfrentar.

\section{Considerações finais}

Queo professor, ao usar a dêixis em sua exposição oral, nem sempre se dá conta de que essa forma de se expressar muitas vezes não atendeàs necessidades de seus alunos, isto é um fato. Que quando das exposições orais, permeadas por enunciações dêiticas, como aqui, ali, aquele, etc., encurta caminho para as compreensões dos conteúdos expostos, disso também ninguém duvida. Porém, o uso deexpressões dêiticas, em particular os espaciais, na grandemaioria das vezes, traz sérios problemas de compreensão para os alunos DVs. Por exemplo, um professor, ao dizer, este aqui é um substantivo, apontando para uma palavra que acabou de escrever no quadro, sem reparar, faz uma substituição importante da informação verbal pela gestual. Ora, seo demonstrativo colocado em foco, para os alunos videntes não chega a ser um problema; para os DVs a situação éoutra.

Um dos grandes problemas observados nesse meio comunicacional está nos referentes dos quais os professores se valem para situar o enunciado. A costumado a um padrão de normalidade, o professor, em sala, costuma dirigirseapenas aos al unos videntes. A contece que, para aulas expositivas, por fazer uso abundantedeelementos dêticos, principalmenteos espaciais, ou, ao fazer retomada de textos sefaz necessário inferir no momento da enunciação dados situacionais diferenciando a forma das explanações. A dependência dessa situação comunicativa podeprivar, o DV deapreender.

Sea inclusão tem avançado muito, isso se deveao fato de queos alunos especiais não vão mais à escol a somente para a social ização. A cobrança de queo aluno DV precisa ser atendido como qual quer aluno considerado normal deixa, de certa forma, o professor meio encabulado. É um tempo muito recente desta nova etapa.

Querer quea relação ensino-aprendizagem defato aconteça éum desejo de todos: educadores, alunos e sociedade. Mas, para que os resultados sejam satisfatórios é necessário abrir discussões com equipes multidisciplinares, incluindo-seaí o próprio aluno esua família.

Quanto à sala de aula, caberá ao professor ficar atento para dar a sua exposição um significado pleno. Devem ser observados o contexto e a situação, articulando seus referentes, na composi ção de unidades lingüísticas, semânticase pragmáticas. Conformelembra Maingueneau (2001), um mesmo dêitico podeestar 
presente em vários paradigmas de uma só vez, porém, mais importante é o uso quesefaz do paradigma, dando a elevalor dêitico, ao se relacionar com o momento da enunciação ou não-dêitico, por dependência de outra forma, onde acontece uma dissociação entre o enunciado e sua instância de enunciação. O importante pois, é ter o cuidado de não deixar espaços vagos, em que a comunicação fica interrompida, provocando no aluno DV a sensação de absoluta incapacidade, o que, além deser desumano, éfalso.

É recomendável, no contexto do ensino-aprendizagem, investigar como a mensagem érecebida pelo DV, qual o mínimo delinguagem necessária para que esse indivíduo a compreenda.

Para, Guimarães (1999, p.12), 'o arsenal de dados que garante a transmissão eassimilação da mensagem develevar em conta o contexto' para poder haver a sintetização do texto ao desenvolver a isotopia ${ }^{8}$ sobre a qual os enunciados devem ser lidos. Faz-se necessário, então, para completar o conteúdo temático na estrutura formal, um bom contexto deinterferências externas, onde o texto passa a existir num processo global de comunicação e de interação entre enunciador e receptor. Estecontexto extraverbal, deacordo com ela, é composto por circunstâncias, objetos e acontecimentos extralingüísticos que necessitam ser conhecidos pelo receptor, para haver a devida compreensão. Segundo a autora, ao fazermos mobilização de componentes diversos, sejam de ordem cognitiva, discursiva, afetiva, sociológica, ou cultural , a mensagem só se concretiza a partir da recriação verbal de dados situacionais, bem como de pressupostos que condicionam sua significação. Veja-sequeénesse ponto quea figura do professor setorna importante. Ele precisa conhecer a turma com a qual trabalhará. Saber quem eles são, como aprendem, quais os recursos que utilizam para estudar, qual a condição física e sensório motora de cada um, é de fundamental importância para o professor. Somente assim ele, o professor, conseguirá preparar o seu material de ensino e exposição de forma adequada que atinja positivamente a todos ea cada um.

\footnotetext{
8 "Isotopia” (do grego isos, igual, semelhante, etopos, plano, lugar) significa plano de sentido, leitura quesefaz deuma frase ou texto.(DICAS..., 2007).
} 


\section{ReferênCIAS}

APOTHÉLOZ, D. Papel e funcionamento da anáfora na dinâmica textual. Coleção clássicos da lingüística. Referenciação/ organizadoras:M.M.Caval cante, B.B. Rodrigues, A .Ciulla. São Paulo: Contexto, 2003.

ARNAULD, A. Gramática de Port-R oyal/ A rnauld eLancelot. Tradução de B.F. Basseto, H.G. Murachco. São Paulo: Martins Fontes, 1992.

BENVENISTE, É. Problemas de lingüística geral. Tradução de M.G. Novak e L. Néri. São Paulo: Comphanhia Editora N acional, 1976.

. 0 H omem na linguagem. Tradução de I.M.L. Pascoal. Lisboa: Vega, 1992.

CAZACU, T.S. Psicolingüística aplicada ao ensino de línguas. Tradução de L.S. Cabral. São Paulo: Pioneira, 1979.

COLL, C. et al. D esenvolvimento psicológico e educação. Tradução de F. Murad. 2.ed. Porto Alegre: Artmed, 2004.

DICAS de Português, www.paulohernandes.pro.br, acesso em 16/ 04/ 2007.

FRAGOSO, L.C.P.L. O D êtico "aí" no discurso oral ea proposta cognitivista. Revista eletrônica do instituto de humanidades. Vol 1. n.4. jan-mar 2003. Disponível em: http:/ / www.unigranrio.br/ unidades_acad/ i hm/ graduacao/ letras/ revista/ numero4/ textoluane.html. A cesso em: 03 set. 2006.

GERALDI, J.V. Linguagem e ensino: exercícios de militância e divulgação. Campinas: Mercado de letras, Associação de leitura do Brasil, 1996.

GUIMARÃES, E. A Articulação do texto. Série princípios. 7.ed. São Paulo: Ática, 1999.

ILARI, R. A lingüística e o ensino da língua portuguesa/ Rodolfo llari. 4.ed. São Paulo: Martins Fontes, 1997.

2000.

. GERALDI, J.W. Semântica. Série Princípios. 10.ed. 2. impressão. São Paulo: Ática,

KOCH, I.V. Texto e coerência/Ingedore Grunfeld Villaça Koch, Luiz Carlos Travaglia. 2.ed. São Paulo: Cortez, 1993.

. 0 texto e a construção dos sentidos. 4.ed. São Paulo: Contexto, 2000.

LAHUD, M. A propósito da noção de dêixis. São Paulo: Ática, 1979.

LYONS, J. Introdução à lingüística teórica. Tradução R.V. Mattos e Silva; H. Pimentel. São Paulo: Ed. Nacional: Ed. da universidade de São Paulo, 1979. LTC, 1987.

. Linguagem e lingüística: uma introdução. Tradução M.W. Averbug. Rio de Janeiro:

MAINGUENEAU, D. Elementos lingüísticos para o texto literário. Tradução M .A.B. Mattos; São Paulo: Martins Fontes, 2001.

BRASIL. Ministério da Educação. Programa de capacitação de recursos humanos do ensino fundamental: deficiência visual. Organização: Bruno, M.S.G. e M ota, M.G.B. Colaboração: Instituto Benjamin Constant, Ministério da Educação, Secretaria de Educação Especial. Brasília, v.1, 2001. 
LAVARDA, S. T. F.; BIDARRA, J.

PEIRCE, C.S. Semiótica. Tradução de J.T.Coelho N eto. São Paulo: Editora Perspectiva S.A, 1995.

PERROT, J. A lingüística. Col eção saber atual. Tradução de M.L.Rodrigues e N .A.M abuchi. São Paulo: Difusão Européia do Livro, 1970.

RECTOR, M. Comunicação não verbal: a gestualidade brasileira/ M. Rector, A.R. Trinta. Petrópolis: Vozes, 1985.

VIGOTSKY, L.S. Fundamentos de defectologia. In: 0 bras completas. Tomo V. Havana: Editorial Pueblo y Educación, 1997.

Recebido em 29/ 05/ 2007

Reformulado em 10/ 10/ 2007

A provado em 30/ 11/ 2007 